\title{
Validating a Blended Teaching Readiness Instrument for Primary/ Secondary Preservice Teachers
}

Douglas Elijah Archibald

Brigham Young University

Follow this and additional works at: https://scholarsarchive.byu.edu/etd

Part of the Education Commons

\section{BYU ScholarsArchive Citation}

Archibald, Douglas Elijah, "Validating a Blended Teaching Readiness Instrument for Primary/Secondary Preservice Teachers" (2020). Theses and Dissertations. 8970.

https://scholarsarchive.byu.edu/etd/8970

This Thesis is brought to you for free and open access by BYU ScholarsArchive. It has been accepted for inclusion in Theses and Dissertations by an authorized administrator of BYU ScholarsArchive. For more information, please contact ellen_amatangelo@byu.edu. 
Validating a Blended Teaching Readiness Instrument for Primary/Secondary Preservice Teachers

Douglas Elijah Archibald

A thesis submitted to the faculty of

Brigham Young University

in partial fulfillment of the requirements for the degree of

Master of Science

Dr. Charles Graham, Chair

Dr. Heather Leary

Dr. Ross Larsen

Department of Instructional Psychology and Technology

Brigham Young University

Copyright (C) 2020 Douglas Elijah Archibald

All Rights Reserved 


\author{
ABSTRACT \\ Validating a Blended Teaching Readiness Instrument for \\ Primary/Secondary Preservice Teachers \\ Douglas Elijah Archibald \\ Department of Instructional Psychology and Technology, BYU \\ Master of Science
}

Blended learning is the fastest-growing modality in North America and much of the world. However, research and training in blended learning is far outpaced by its usage. To remedy this gap, we developed a competency framework and self-survey instrument to help teachers and researchers evaluate teacher readiness for blended environments. The purpose of this research is to prove that the model and accompanying survey instrument are reliable for use with teacher candidates both before and after going through a blended teaching course. To accomplish this, we sent out a survey instrument to 326 teacher candidates studying in a blended teaching course at a university in the western United States. The teachers took the survey at the beginning of class, and then once again, three months later. Using confirmatory factor analysis, we determined that the pre-class survey results fell within the range of the four fit statistics cutoffs (RMSEA $=.056, \mathrm{CFI}=.906, \mathrm{TLI}=0.900, \mathrm{SRMR}=.04)$. And with slight modification, the post-class survey results did as well $(\mathrm{RMSEA}=.052, \mathrm{CFI}=.914, \mathrm{TLI}=.907$, and SRMR .058). We also showed that the factor loadings and communalities were statistically significant. By testing the factors in this way, we make a case for the survey to be a valid and reliable instrument in assessing teacher competency, and make a case for thinking of blended teaching competencies in terms of our model. We then tested for measurement invariance, but were unsuccessful in making a case for it. The results of our findings provide teacher educators, teacher candidates, and researchers a new pedagogically-oriented framework and scientifically validated self-survey to use in order to improve and personalize teacher education and professional development for blended settings.

Keywords: K-12 blended learning, blended teaching competencies 


\section{ACKNOWLEDGMENTS}

This thesis would not have been possible without the stalwart support of my loving wife, Amanda, who took excellent care of me and our home while I spent many long days and nights completing this work. She is also the most fantastic sounding board for my ideas, as well as a much-needed grammarian to correct my syntax errors.

I am also indebted to the kind and nurturing support of my chair, Dr. Charles Graham, who taught me so much throughout this process, and unwaveringly believed in me through the many twists and turns and surprises this research had in store for us. He kept me on the right track and in the right frame of mind to do what needed to be done.

I also acknowledge the support from the other two members of my committee. First, Dr. Ross Larsen, who patiently made time to teach me multiple semesters' worth of structural equation modeling in a very condensed time frame. Second, Dr. Heather Leary who has been an integral part of the review process, providing a fresh pair of eyes and perspective to all the research I did. She was also an invaluable tutor to me, helping me land my first publication and write my first journal article.

I would like to thank my predecessor in this work, who also happens to be my current boss: Emily Pulham. As one of the previous researchers on this project, her brilliant and welldocumented reports made it easy to carry this work forward. As my boss, she has been very patient and understanding, allowing me to have the time and flexibility I needed in order to eventually complete this thesis.

Finally, I express my gratitude to my parents, Margaret and Jim, for all they taught me, and the counsel they gave me throughout this process. 


\section{TABLE OF CONTENTS}

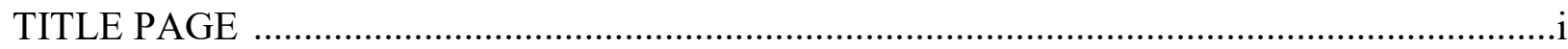

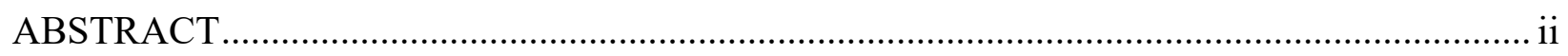

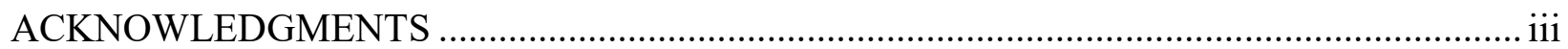

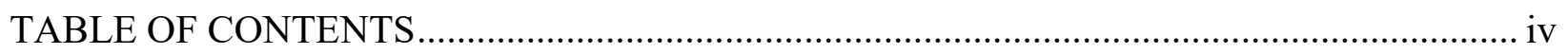

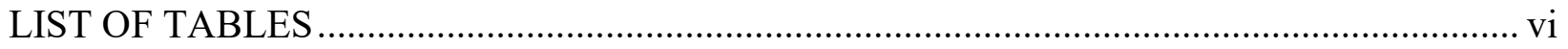

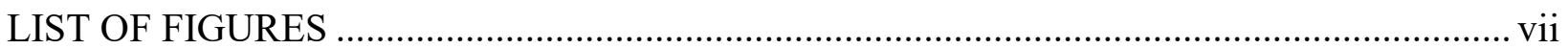

DESCRIPTION OF THESIS STRUCTURE................................................................. viii

ARTICLE: Validating a Blended Teaching Readiness Instrument for Primary/Secondary

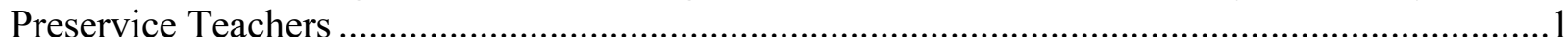

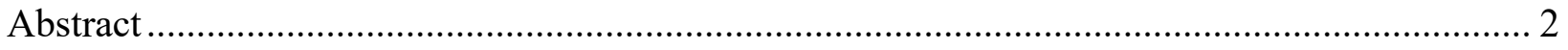

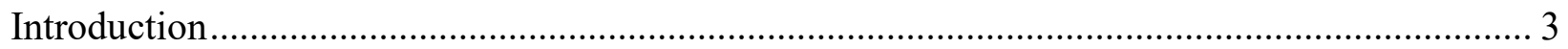

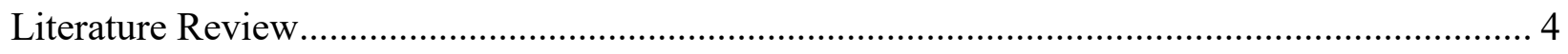

Growth and Adoption of Primary and Secondary Blended Learning .................................. 4

Teacher Preparation ..................................................................................................... 5

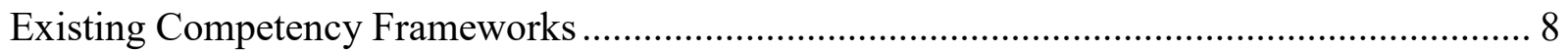

Graham et al., Competency Framework Phase 1 and 2 .............................................. 8

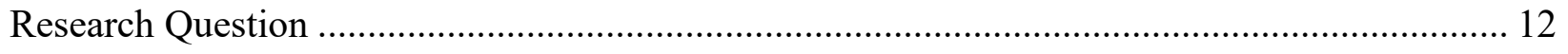

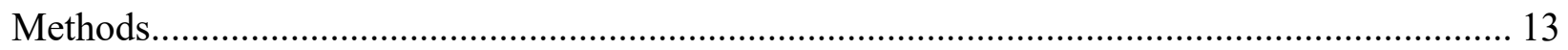

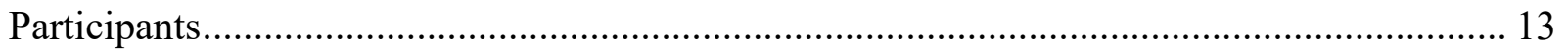

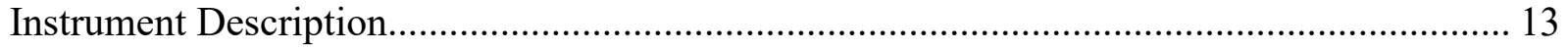

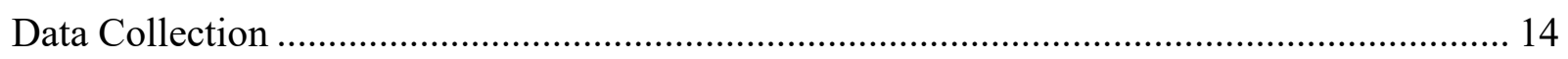

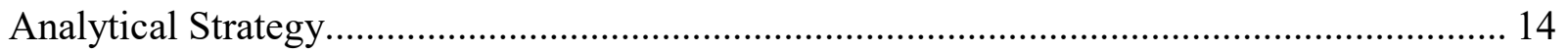

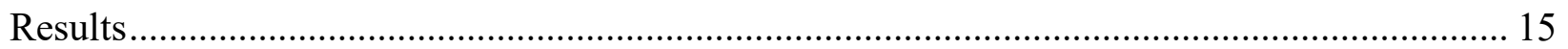




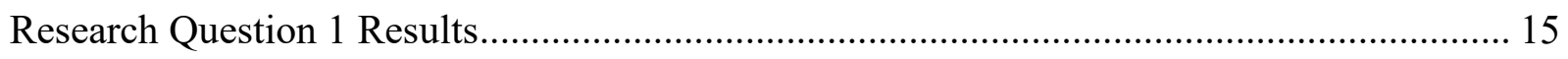

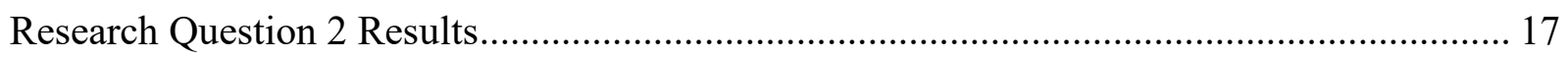

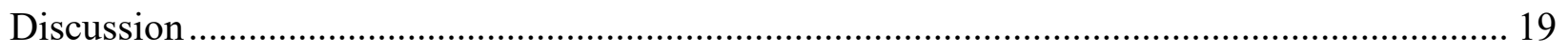

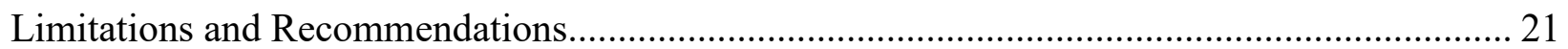

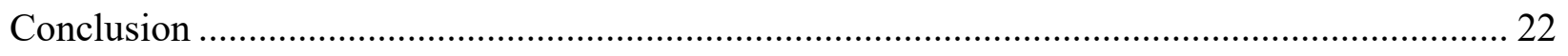

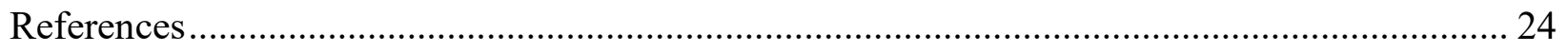

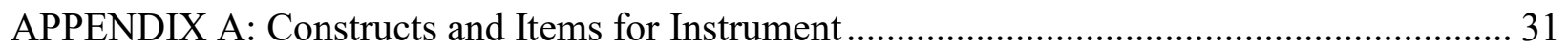

APPENDIX B: Institutional Review Board Approval Letter ……................................................ 38

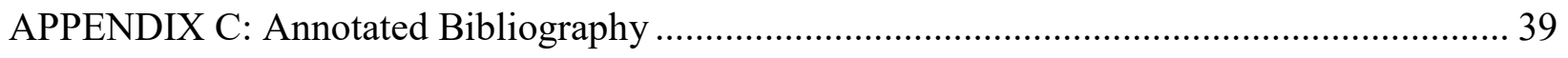

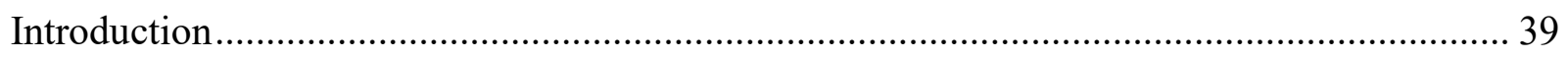

Blended Learning Definitions and Trends ........................................................................... 40

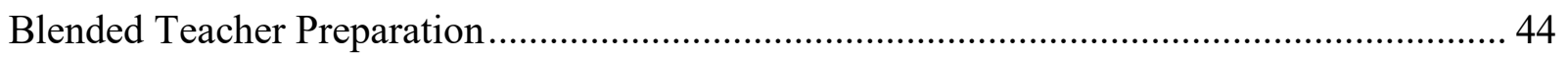

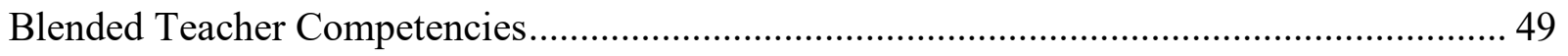

Developing and Validating Blended Theory …………....................................................... 52 


\section{LIST OF TABLES}

Table 1 Description of the Top-Level Constructs in the K-12 BTR Model...............................11

Table 2 Correlation of Competencies in the BTR Model Pre-Class Survey........................... 17

Table 3 Correlation of Competencies in the BTR Model Post-Class Survey .........................17

Table 4 Results of Three-Step Test to Determine Metric Invariance......................................19

Table A1 Confirmatory Factor Analysis Results (STDYX Standardization) for Blended Teaching Readiness Model Pre-Class Survey with Each Item's Description $(N=258$

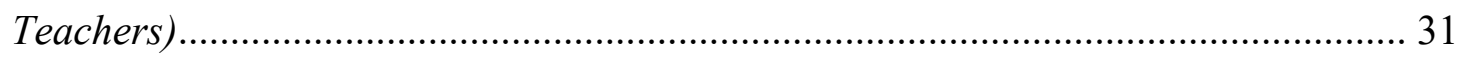

Table A2 Confirmatory Factor Analysis Results (STDYX Standardization) for Blended Teaching Readiness Model Post-Class Survey with Each Item's Description (N=188

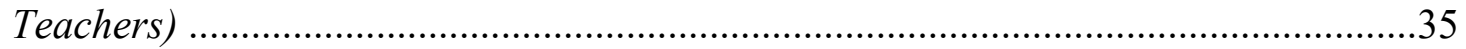




\section{LIST OF FIGURES}

Figure 1. Proposed model formulation for Dispositions and the four competencies and how they relate to the survey items. 


\section{DESCRIPTION OF THESIS STRUCTURE \\ Validating a Blended Teaching Readiness Instrument for Primary/Secondary Preservice}

Teachers is written in a journal-ready article format, meaning that it is a mix between traditional thesis requirements and the format used by education research journals. The journal I hope to publish this thesis in would be a Tier 1 international journal addressing educational technology

for an audience that includes both fellow researchers as well as general teacher and teacher educators. Consequently, while the preliminary pages of this thesis reflect the requirements for submission to the university, the report is presented as a journal article and thus conforms to their requirements regarding length and style for the specific journal I have in mind. The first section is my journal article. Succeeding it are the related appendices for the article. Appendix A is a description of each item in the survey instrument along with the results from the confirmatory factor analysis. Appendix B is a copy of the email we received from the institutional review board approving the class data we would be using in this analysis. Appendix $\mathrm{C}$ is an annotated bibliography of seminal and significant sources for this thesis as required by the Instructional Psychology and Technology Department at BYU. 


\section{ARTICLE}

\section{Validating A Blended Teaching Readiness Instrument For}

Primary/Secondary Preservice Teachers

Douglas E. Archibald

Charles R. Graham

Ross Larsen

Brigham Young University 


\begin{abstract}
Blended learning is the fastest-growing modality in North America and much of the world. However, research and training in blended learning is far outpaced by its usage. To remedy this gap, we developed a competency framework and self-survey instrument to help teachers and researchers evaluate teacher readiness for blended environments. The purpose of this research is to prove that the model and accompanying survey instrument are reliable for use with teacher candidates both before and after going through a blended teaching course. To accomplish this, we sent out a survey instrument to 326 teacher candidates studying in a blended teaching course at a university in the western United States. The teachers took the survey at the beginning of class, and then once again, three months later. Using confirmatory factor analysis, we determined that the pre-class survey results fell within the range of the four fit statistics cutoffs $(\mathrm{RMSEA}=.056, \mathrm{CFI}=.906, \mathrm{TLI}=0.900, \mathrm{SRMR}=.04)$. And with slight modification, the postclass survey results did as well (RMSEA =.052, $\mathrm{CFI}=.914, \mathrm{TLI}=.907$, and $\mathrm{SRMR} .058)$. We also showed that the factor loadings and communalities were statistically significant. By testing the factors in this way, we make a case for the survey to be a valid and reliable instrument in assessing teacher competency, and make a case for thinking of blended teaching competencies in terms of our model. We then tested for measurement invariance, but were unsuccessful in making a case for it. The results of our findings provide teacher educators, teacher candidates, and researchers a new pedagogically-oriented framework and scientifically validated self-survey to use in order to improve and personalize teacher education and professional development for blended settings.
\end{abstract}

Keywords: K-12 blended learning, blended teaching competencies 


\section{Introduction}

Blended learning (BL) is the combination of face-to-face and online modalities of instruction (Graham, 2006, 2013). Because of its ability to leverage the strengths of both modalities, blended learning is becoming more and more prevalent in primary and secondary education in the United States (Watson, Murin, Vashaw, Gemin, \& Rapp, 2011).

Although states and school districts are moving forward with the implementation of blended learning at an accelerated rate, teacher preparation lags far behind (Graziano \& BryansBongey, 2018). This can be traced back to the fact that research in this field is also in its infancy (Graham, Henrie, \& Gibbons, 2014). Until 2018, there was no scientifically validated set of competencies specific to the skills needed for blended teaching (Pulham, Graham, \& Short, 2018; Graham, Borup, Pulham, \& Larsen, 2019). Scientifically validated competencies can provide direction and confidence to suppliers of teacher preparation and professional development that their efforts are properly focused. Additionally, for a competency framework to connect to practice, it should include an instrument for reliably measuring the competencies (Burkhardt \& Schoenfeld, 2003). In this way, teachers and school administrators can diagnose what training is needed as well as the effectiveness of any professional development that is implemented.

This need for a competency framework and measurement instrument provided the impetus for us to embark on a two-year journey to develop primary and secondary blended teacher competencies along with its corresponding survey instruments to measure blended teacher readiness (Graham, Borup, Pulham, \& Larsen, 2017). These efforts began with in-depth literature reviews identifying blended competencies (Graham et al., 2017; Graham, Borup, Pulham, \& Larsen, 2018). This led to the development of a new competency framework. 
Following the development of the competencies came the first iteration of the survey instrument to measure teacher readiness according to the competencies (Pulham et al., 2018; Graham et al. 2019). Though the first instrument was successfully validated, because of excessive length and complexity, we came to appreciate the need for developing a more concise instrument in order for it to be of practical use in educational settings (Graham et al., 2019).

The purpose of this research is to validate a new and more concise survey instrument using confirmatory factor analysis (Wang \& Wang, 2012). Once validated, the instrument's data can be evaluated, providing for deeper insights into teachers' acumen in regards to the distinct skills of blended teaching. This will allow teacher educators to identify what areas need to be targeted for improvement to personalize coursework for teacher candidates. School district leaders will be able to support their implementation and evaluation of BL initiatives.

Researchers will be able to use the data to explore the success of professional development efforts. Additionally, we hope that the instrument will allow teachers and teacher educators to find actionable ways to bridge the gaps in confidence and competence with blended teaching.

\section{Literature Review}

The existing corpus of BL literature provides insights into the growth and adoption of BL across primary and secondary schools throughout the world. It also highlights how teacher preparation has lagged behind adoption within school settings. The literature illustrates how a competency framework could alleviate this issue, and addresses attempts made at developing competency frameworks along with their strengths and limitations.

\section{Growth and Adoption of Primary and Secondary Blended Learning}

Between 2011 and 2016, the number of US students enrolled in blended classrooms reportedly increased by $80 \%$, with a 40\% increase (or 10,490 students) between 2015 and 2016 
alone (Molnar et al., 2017; Watson et al., 2015). In Canada, there has been a similar accelerated growth; in 2015 there were an estimated 343,000 students in blended environments, and in two years that number went on to exceed 657,000 students - a 91\% growth (Barbour \& LaBonte, 2017). There is evidence that these figures, as dramatic as they are, are actually underreporting the growth of BL (Graham, 2019). Graham (2019) reports that almost all of the growth of reported "digital learning" actually corresponds to blended learning exclusively. This is because many state and district digital learning programs reported as "online" are in fact blended programs (Barbour, 2008; Freidhoff, Borup, Stimson, \& DeBruler, 2015; Taylor et al., 2016; Watson et al., 2011).

Throughout the rest of the world, BL has also grown more prevalent. Most urban areas and large schools in North America, Western Europe, Asia, and Oceania have BL functioning in some capacity (Barbour et al., 2011). In a study of 54 countries, researchers for the International Association for K-12 Online Learning (iNACOL) found that BL opportunities were provided for at least some primary and secondary students (Barbour et al., 2011). However, in other parts of the world, far more students can be served. In China and India, where the amounts of students at a school can be staggering and internet access is steadily increasing, tens of thousands of students at a single institution are often served through teleconferences and asynchronous submissions as well as other forms of blending (Barbour et al., 2011; Bonk, 2012).

\section{Teacher Preparation}

Tied to the rise in demand for more blended classes is the rise in demand for qualified teachers who can teach in blended contexts. However, blended teaching requires distinct skills and dispositions specific to this unique modality making it so that a standard teacher preparation course of study is insufficient (Bonk, Kim, \& Zeng, 2005; Brodersen \& Melluzzo, 2017; Davis et 
al., 2007; Horn \& Staker, 2014). For example, blended teaching is unique in its consistent utilization of mastery-based learning (Horn \& Staker, 2014). Blended teachers, unlike traditional teachers, have a cocktail of communication possibilities far beyond lecturing that require new skills and awarenesses to execute successfully (Brodersen \& Melluzzo, 2017). These teachers have communication tools that range from online discussion boards, to personalized feedback, to virtual lectures, to video calls. Blended teachers are expected to play significantly more roles than regular teachers. Blended teachers, in addition to being lecturers, counselors, and mentors to their students as most teachers are, are also expected to act as facilitators, instructional designers, site coordinators, and network administrators for their schools, classrooms, and fellow teachers (Ferdig, Cavanaugh, Dipietro, Black, \& Dawson, 2009).

As a result of the difficulty in mastering teaching techniques like the above and many others in these novel environments, a few states in the US such as Maryland, Minnesota, and Utah have updated requirements for teacher licensure to include coursework preparing preservice teachers "to teach effectively in... blended classrooms" and "to facilitate student use of software for personalized learning” (Utah Department of Administrative Services, 2016; see also Archambault, Debruler, \& Freidhoff, 2014). In British Columbia, Canada, the Ministry of Education requires distributed learning schools to hire "only educators with training or experience in distributed learning methods and to provide ongoing training and professional development on distributed learning (Barbour et al., 2011, p. 12).” In Asia, city states like Hong Kong and Singapore require teachers to receive some training in online integration (Barbour et al., 2011). In Europe, Slovenian teachers attend conferences on blended teaching, and in Spain teachers are provided with free online training courses (Barbour et al., 2011). 
Despite the efforts of these states and countries, however, the overwhelming majority of states, countries, and provinces have no legislation regarding blended teacher preparation for preservice teachers (Archambault, Debruler, \& Freidhoff, 2014; Barbour et al., 2011; Barbour \& LaBonte, 2017). Barbour and his fellow iNACOL (2011) researchers conclude:

There is an international lack of focus on teacher training. This lack of training is not only in the use of new technologies, but also in the methodology and pedagogy necessary to fully understand how and why technology can positively impact student performance when in the hands of a competent, highly qualified teacher (p. 17).

The US National Education Policy Center noted that since 2015, not a single state has contributed any new legislation or policies to ensure blended teacher quality (Molnar et al., 2017). Consequently, teachers generally receive no training to teach in these contexts (Graziano \& Bryans-Bongey, 2018), nor do they typically receive any hands-on practice teaching in these contexts through field experiences (Archambault et al., 2016). Archambault et al. (2016) found that only $4.1 \%$ of responding teacher preparation programs provided opportunities for field experiences in online teaching. Davis et al. (2007) estimate that 86,000 American teacher candidates graduate each year without any digital teaching skills.

Inservice teachers are also not receiving the preparation they need. Barbour, Siko, Gross, and Waddell (2013) report that less than $40 \%$ of online and blended teachers received any professional development before being asked to teach a digital class. Without the proper infrastructure and pedagogical support, inservice teachers are far less likely to attempt blended learning in their classroom (Porter \& Graham, 2016). Many experienced online and blended teachers report that they would like more professional development in regards to the skills of 
online and blended learning. Specifically, they mentioned more training in learning communication technologies, time management strategies, risks of academic dishonesty to learners, and student internet safety (Dawley, Rice, \& Hinck, 2010). There is a need for preparing teachers to be effective in blended learning classrooms.

\section{Existing Competency Frameworks}

Competencies are knowledge, skills, attitudes, and behaviors that enable someone to "effectively perform the activities of a given occupation or function to the standards expected in employment" (Sims \& Koszalka, 2008, p. 569). Consequently, competency frameworks are a necessary element in any teacher preparation program as they can provide teachers a personalized diagnosis of the knowledge, skills, and attitudes they need to have to be successful (Pulham \& Graham, 2018). Several attempts have been made in the field to develop competency frameworks for blended teachers (Dawley et al., 2010; DiPietro, Ferdig, Black, \& Preston, 2008; Foulger, Graziano, Schmidt-Crawford, \& Slykhuis, 2017; Oliver, 2014; Powell, Rabbitt, \& Kennedy, 2014). However, research done by Pulham et al. (2018) identified only $8 \%$ of the competencies within these frameworks were specific to a blended modality. Additionally, they identified that $57 \%$ of these competencies were written so generically they applied to all teaching modalities (Pulham et al., 2018). Generally, these competencies did not differentiate blended skills from skills needed for a fully-online or merely a technology-rich traditional classroom. Nor was there evidence that they were scientifically validated, with the exception of an instrument that was proprietary, the Oliver Framework of Blended Instruction (Oliver, 2014).

\section{Graham et al. Competency Framework Phase 1 and 2}

The K-12 blended teaching competency framework in this paper builds upon the previous work done by Graham et al. (2019). The initial framework went through a three year 
development cycle that is documented through a number of publications (Graham et al., 2017, 2018, 2019; Pulham \& Graham, 2018; Pulham et al., 2018). Part-way into the validation process, researchers began to realize the need to make the framework more parsimonious if the framework was going to be of practical use to teachers and districts (Whetten, 1989). One participant lamented, "[it was] waaaaay too long” (Graham et al., 2019, p. 13). This participant had a point. With five second-order constructs, 13 first-order constructs, 65 survey items, and demographic questions, the instrument was too complex. We saw that this would become a serious problem as we were hoping teachers would want to take the survey multiple times to gauge their improvement and continue growing. This outcome seemed increasingly unlikely given that survey length is negatively correlated with response rates (Fan \& Yan, 2010). Additionally, high correlations between second-order factors, and the fact that many themes cut across multiple constructs, we surmised that we could create a less redundant, more concise instrument.

We had gained many new insights from a recent literature review comparing primary and secondary online and blended global themes (Pulham \& Graham, 2018). In seeing the major themes spelled out before us, we realized a number of aspects about our competency framework needed to be changed. We moved away from the linear process-oriented approach that had been used in some models in favor of a framework that focused on key dispositions and four pedagogically-oriented competencies (see Klein, Spector, Grabowski, \& de la Teja, 2004; Oliver, 2014). Whetten (1989) provides some important guidance for balancing parsimony and completeness when trying to create a model that makes a theoretical contribution. We decided to give up some of the completeness of the first model in favor of increased parsimony. In doing this we made the conscious decision to focus on a handful of the most essential competencies. In 
order to identify the most essential competencies, we drew on a comprehensive literature review that coded and ranked all existing K-12 blended teaching standards (Pulham \& Graham, 2018). The resulting framework consists of Disposition along with four competencies: Online Integration, Personalization, Online Interaction, and Data Practices (Graham et al., 2019). The competencies were developed in part using the methods laid out in Bigatel, Ragan, Kennan, May, and Redmond (2012). For more information about the research identifying the dispositions and the four competencies see Table 1. For a visual depiction of the theoretical relationships between the competencies and the items see Figure 1. 
Table 1

Description of the Top-Level Constructs in the K-12 BTR Model

\begin{tabular}{|c|c|c|}
\hline Construct & $\begin{array}{c}\text { Related Organizing Theme \& Rank (from } \\
\text { Pulham \& Graham, 2018) }\end{array}$ & Relevant Sources \\
\hline Dispositions & -Student-centered learning (\#8) & $\begin{array}{l}\text { (Pulham \& Graham, 2018, p. 424; Powell } \\
\text { et al., 2014, p. 10-12; Bjeki, Krneta, \& } \\
\text { Milo, 2010; Oliver \& Stallings, 2014, p. } \\
\text { 91-94; The Learning Accelerator, n.d.) }\end{array}$ \\
\hline $\begin{array}{l}\text { Online Integration \& } \\
\text { Management }\end{array}$ & $\begin{array}{l}\text {-Expectations established (\#4) } \\
\text {-Classroom management }(\# 6) \\
\text {-Integration of online and face-to-face } \\
\text { elements (\#8) } \\
\text {-General assessment (\#11) } \\
\text {-Software management }(\# 12)\end{array}$ & $\begin{array}{l}\text { (Pulham \& Graham, 2018, p. 422-423; } \\
\text { Oliver, 2014, p. 2; Arney, 2015, p. 254; } \\
\text { ISTE, 2008; Tucker, 2012) }\end{array}$ \\
\hline Data Practices & $\begin{array}{l}\text {-Mastery based learning (\#2) } \\
\text {-Data usage and interpretation (\#3) } \\
\text {-Learning Management System (\#7) } \\
\text {-Formative assessment (\#15) }\end{array}$ & $\begin{array}{l}\text { (Pulham \& Graham, 2018, p. 414-415; } \\
\text { Staker, 2011, p. 14; The Learning } \\
\text { Accelerator, n.d.; Johnson, 2014) }\end{array}$ \\
\hline Personalization & $\begin{array}{l}\text {-Flexibility \& personalization (\#1) } \\
\text {-Student progress review (\#5) } \\
\text {-Student grouping (\#10) } \\
\text {-Instructional intervention (\#15) }\end{array}$ & (Powell et al., 2014, p. 10) \\
\hline Online Interaction & $\begin{array}{l}\text {-Community development (\#12) } \\
\text {-Online discussion facilitation (\#14) }\end{array}$ & $\begin{array}{l}\text { (Tucker, 2012, p. 38; National Education } \\
\text { Association, 2006, p. 17; Bjeki et al., } \\
\text { 2010) }\end{array}$ \\
\hline
\end{tabular}



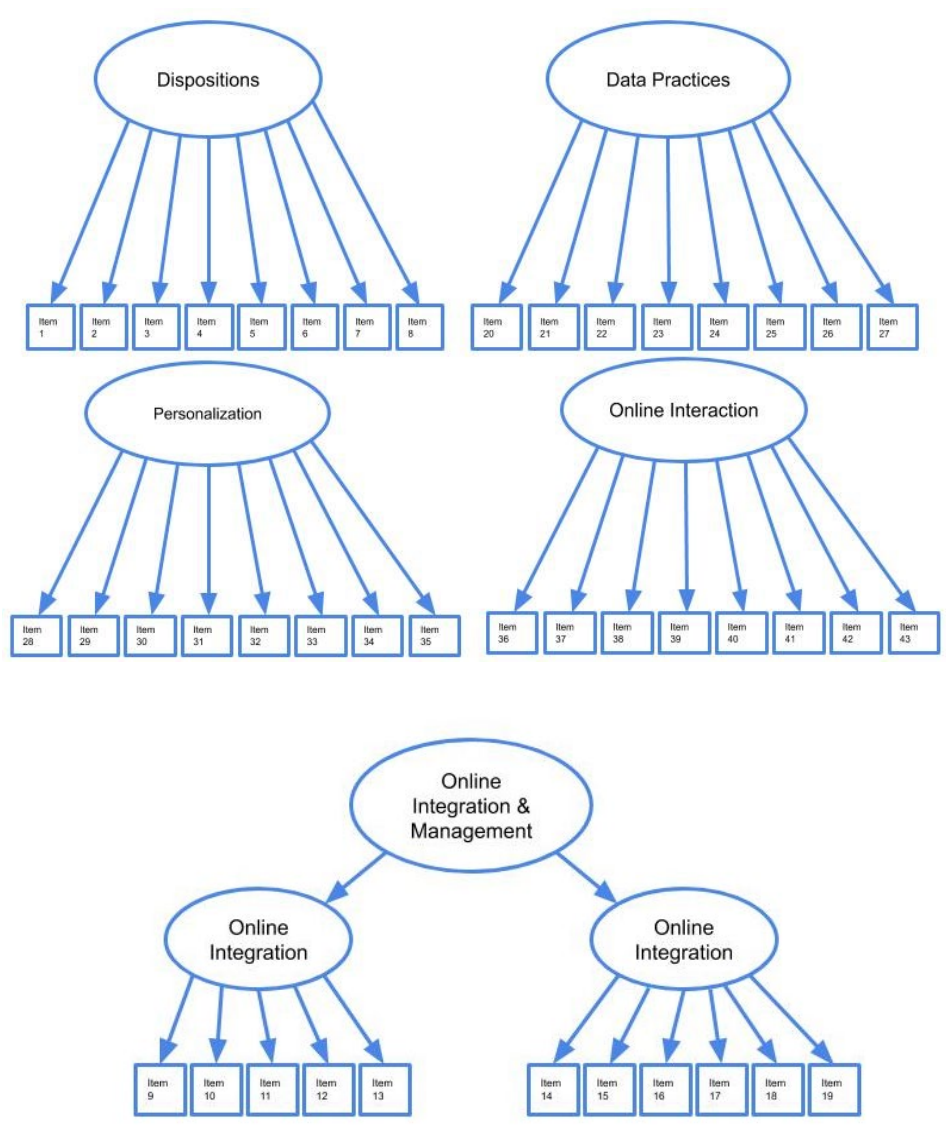

Figure 1. Proposed model formulation for Dispositions and the four competencies and how they relate to the survey items.

\section{Research Question}

The purpose of this research was to validate the psychometric properties of our abridged competency framework for primary and secondary blended teachers and validate the streamlined survey instrument to use for preservice teacher development. The crux of this research hangs on two questions: (1) Does the model for the blended teaching readiness (BTR) competencies fit the data well at pre-class and post-class survey administration? (2) Is there measurement invariance (same scale and constructs) from pre-class to post-class survey administration for the BTR competencies? 


\section{Methods}

In this section, we will discuss the preservice teachers who participated in this research. Additionally, we will touch on the nature of our survey instrument and data collection. Finally, we explore our strategy for dealing with our two research questions.

\section{Participants}

The participants for this study were preservice K-12 teachers enrolled in a blended teaching course at a university education department in the western United States in 2019. Three hundred twenty-six preservice teachers took the survey. They were all asked to take the survey twice, once before the course began, and again after their completion of the course. However, because of students dropping out, using a different email or device to take the survey, not completing the entire survey, typos in filling out their information into the survey, the post-class survey being taken as part of a final examination process, and the anonymization process to protect student data we were only able to match 156 pre-class and post-class surveys. Altogether, we had a total of 290 pre-class survey responses, and 188 post-class survey responses.

\section{Instrument Description}

The survey was created on Qualtrics. It had five sections, one for each of the four competencies and the dispositions section. Each section had eight statements, with the exception of online integration which had 11. Participants rated the accuracy of each statement on a scale of one to six with "one" signifying very limited competence or agreement, and "six" signifying high competence or agreement. The Dispositions statements were all "I believe..." statements where participants indicated how much they agreed with phrases like, "I believe that student learning is enriched when teachers and students interact in online discussions.” The competency 
statements asked participants to rate their ability to perform actions such as "determine when it is best to use computer-administered assessments." The rest of the survey questions can be viewed in Appendix A. To complete the entire survey took 5-15 minutes. Time-pressed participants also had the option to take individual sections of it.

\section{Data Collection}

Survey forms were distributed to the preservice teachers via an anonymous link connecting to Qualtrics. Data was recorded and saved on the Qualtrics server. There was a high rate of response from the preservice teachers since taking this survey was a required part of their coursework for teacher licensure. The post-class surveys were taken one semester (about three months) after the pre-class survey. All personal data was anonymized via encryption to ensure student security.

\section{Analytical Strategy}

To answer the question "does the model for the blended teaching readiness (BTR) competencies fit the data well at pre-class and post-class survey administration?", we needed to run a confirmatory factor analysis (CFA) on both the pre-class and post-class survey data individually. CFA is a type of structural equation modeling used in situations where the dimensionality of the variables (in this case the four blended teaching competencies and dispositions) is known (Bollen, 1989; Brown, 2006). Before running a CFA, certain assumptions need to be met including: linearity, independence, normality, no extreme multicollinearity, and no outliers. These were determined through an examination of correlations, scatter plots and histograms in IBM's statistical software, SPSS. To determine model fit we ran the CFA using Mplus 8.3. We then determined fit by using traditional fit statistics and their cutoffs as 
established by the literature $(\mathrm{RMSEA}<.08, \mathrm{CFI}>.9, \mathrm{TLI}>.9, \mathrm{SRMR}<.08$; Wang \& Wang, 2012).

We then needed to answer the second research question, "is there measurement invariance (i.e., same scale and constructs) from pre-class to post-class survey administration for the BTR competencies?" To demonstrate measurement invariance, there is a three step process consisting of (1) testing for configural invariance (i.e., same structure across time), (2) testing for metric invariance (i.e., same structure and factor loadings across time), and (3) testing for scalar invariance (i.e., same structure, factor loadings, and intercepts over time). We performed this process using the fit statistics maintained by Wang and Wang (2012) for the configural invariance, and then using Chen's (2007) guidelines (CFI changes less than or equal to -0.010) to determine the significance of the results of the metric and scalar invariance tests.

\section{Results}

In this section, we first examine the results of the CFA for pre-class and post-class data to determine model fit, and then we use the three step process to determine if there is measurement invariance.

\section{Research Question 1 Results}

When we tested the pre-class survey data for the assumptions of normality (linearity, independence, normality, no extreme multicollinearity, and no outliers), we found that these assumptions held true. We then ran the CFA for the pre-class survey, and the model met the cutoffs for all of the fit statistics $(\mathrm{RMSEA}=.056, \mathrm{CFI}=.906, \mathrm{TLI}=0.900, \mathrm{SRMR}=.04)$. See Table A1 for individual item factor loadings. The correlations from the CFA between the competencies are displayed in Table 2. The correlation between data practices and personalization was higher than .85 , which indicates potentially poor discriminant validity 
(Farrell \& Rudd, 2009). To test if this was a problem, we ran the model with Data Practices and Personalization combined, and found that it made the fit worse $(\mathrm{RMSEA}=.064, \mathrm{CFI}=.878$, $\mathrm{TLI}=.871$, SRMR=.051). So, we felt justified keeping the model the way it was.

We then tested the post-class survey data for the assumptions of normality. We found that the assumptions for normality held for all of the competency areas, except for the items in the Dispositions construct. Dispositions' items had a strong negative skew, and the range of responses for each item were far more limited in the post-class Dispositions items than in the pre-class items. On three of the eight items, the sample teachers' level of agreement equaled to or exceeded a four out of six. In one sense, this was a positive outcome as one purpose of the course was to positively influence preservice teacher dispositions towards blended teaching. However, this may also hint at a possible ceiling effect for Dispositions. Either way, the Dispositions competency needed to be dropped for the post-class CFA. After running the CFA, we found good fit for only two of the four statistics cutoffs (RMSEA $=.059, \mathrm{CFI}=.890, \mathrm{TLI}=.882$, $\mathrm{SRMR}=.059)$. So, we correlated the error terms of two related items: Online Interaction items one and two. Both of these items deal with relationship expectations and boundaries within online communication, and both have some similar wording. After correlating these error terms, we ended up within the cutoffs for all four fit statistics prescribed by the literature $(\mathrm{RMSEA}=.052, \mathrm{CFI}=.914, \mathrm{TLI}=.907$, and SRMR .058). See Table A2 for more detailed information about the individual item factor loadings. The correlations between the competencies can be found in Table 3. This time, the correlation between Personalization and Online Interaction were high, and so we tested the model with these combined, and again the fit was made worse $(\mathrm{RMSEA}=.059, \mathrm{CFI}=.891, \mathrm{TLI}=.883, \mathrm{SRMR}=.059)$. So, we felt justified keeping the model the same again. 
Table 2

Correlation of Competencies in the BTR Model Pre-Class Survey

\begin{tabular}{lccccc}
\hline Variable & 1 & 2 & 3 & 4 & 5 \\
\hline 1 Dispositions & 1.000 & & & \\
2 Online Integration \& & $.309^{* *}$ & 1.000 & & \\
Management & & & & \\
3 Data Practices & $.143^{*}$ & $.812^{* *}$ & 1.000 & & \\
4 Personalization & $.189^{*}$ & $.847^{* *}$ & $.866^{* *}$ & 1.000 & \\
5 Online Interaction & $.249^{* *}$ & $.803^{* *}$ & $.748^{* *}$ & $.810^{* *}$ & 1.000 \\
\hline
\end{tabular}

$* * \mathrm{p}<.01, * \mathrm{p}<.05$

Table 3

Correlation of Competencies in the BTR Model Post-Class Survey

\begin{tabular}{lcccc}
\hline Variable & 1 & 2 & 3 & 4 \\
\hline $\begin{array}{l}1 \text { Online Integration \& } \\
\text { Management }\end{array}$ & 1.000 & & & \\
2 Data Practices & $.822^{* *}$ & 1.000 & & \\
3 Personalization & $.835^{* *}$ & $.829^{* *}$ & 1.000 & \\
4 Online Interaction & $.850^{* *}$ & $.697^{* *}$ & $.862^{* *}$ & 1.000 \\
\hline
\end{tabular}

$* * \mathrm{p}<.01, * \mathrm{p}<.05$

\section{Research Question 2 Results}

We then attempted to answer our second research question: Is there measurement invariance from pre-class to post-class survey administration for the BTR competencies? Measurement invariance between pre and post survey would give us greater confidence in our ability to use the survey for growth modeling. In order to do this, we first ran a configural invariance analysis of the pre-class and post-class surveys with the Dispositions competency dropped, and the Online Interaction items one and two correlated for the post-class survey. The 
resulting fit statistics were not within the cutoffs $(\mathrm{RMSEA}=.046, \mathrm{CFI}=.876, \mathrm{TLI}=.869$, SRMR=.089). We then tried several modifications in an attempt to get the model to fit, even trying eight modifications at one point $(\mathrm{RMSEA}=.043, \mathrm{CFI}=.895, \mathrm{TLI}=.889, \mathrm{SRMR}=.086)$. The fact that we could not get the pre-class and post-class combined configural invariance model to fit, despite the models for pre-class and post-class fitting separately as discussed in the section above, suggests that we did not have sufficient data to perform an analysis on a model with this level of complexity. A similar event happened in our previous research with the development of earlier model (see Graham et al., 2018, 2019).

We then proceeded to examine each competency separately, thus reducing the complexity to a manageable level. We found that each individual competency did fall within the fit statistics for the configural invariance test (i.e., same structure across time) by themselves. This is evidence that the model was indeed too complex to run all of them together. We then tested for metric invariance for each individual competency (i.e., same structure and factor loadings over time), and then scalar invariance if they passed the metric invariance test (i.e., same structure, factor loadings, and intercepts over time). The results of each of the three tests (configural, metric, and scalar invariance) can be found in Table 4 along with a detailing of whether or not these results pass the standards laid out by Chen (2007). Essentially, the standards laid out in Chen (2007) are that for configural invariance, the CFI must be above .9, and for metric and scalar invariance the change in CFI between each test bust be less than or equal to -.005. We found that, according to the standards laid out by Chen (2007), none of the competencies conclusively had measurement invariance. Although, Online Interaction did have metric invariance. 
Table 4

Results of Three-Step Test to Determine Metric Invariance

\begin{tabular}{llccc}
\hline Variable & Analysis & CFI & $\Delta$ CFI & $\begin{array}{c}\text { Meets Requirements } \\
\text { from Chen (2007) }\end{array}$ \\
\hline Entire model & 1. Configural Invariance & $.876^{* *}$ & No \\
& 2. Metric Invariance & NA & NA \\
& 3. Scalar Invariance & NA & NA \\
Online Integration & 1. Configural Invariance & $.947^{* *}$ & & Yes \\
$\&$ Management & 2. Metric Invariance & $.958^{* *}$ & +.011 & No \\
& 3. Scalar Invariance & NA & & NA \\
Data Practices & 1. Configural Invariance & $.966^{* *}$ & & Yes \\
& 2. Metric Invariance & $.967^{* *}$ & +.001 & No \\
& 3. Scalar Invariance & NA & & NA \\
Personalization & 1. Configural Invariance & $.966^{* *}$ & & Yes \\
& 2. Metric Invariance & $.981^{* *}$ & +.020 & No \\
& 3. Scalar Invariance & NA & & NA \\
Online Interaction & 1. Configural Invariance & $.977^{* *}$ & & Yes \\
& 2. Metric Invariance & $.952^{* *}$ & -.025 & Yes \\
& 3. Scalar Invariance & $.955^{* *}$ & +.003 & No \\
\hline
\end{tabular}

$* * p<.01$

\section{Discussion}

In this study, we set out to create an easy-to-use and blended teaching competency model. We then created an accompanying survey instrument, so that teachers could use the model to identify their strengths and weaknesses in blended teaching. As part of that research, we wanted to discover if survey responses within each competency domain of our proposed model converged and were valid for a population of preservice teachers in the western United States. We found that this was the case for the preservice teachers $(n=290)$ taking the pre-class survey. And with the modification of dropping the Dispositions competency and correlating two items' error terms, we found this to be the case for the teachers taking the post-class survey as well, despite the smaller sample size $(n=188)$. 
It is possible that if we had been able to collect more post-survey data, the Dispositions competency would have been more normal and have a larger variance so it too could be eligible for validation. However, as Flowers (2006) writes regarding the distribution of her preservice teacher dispositions, "in practice, it is not expected that the data would be normally distributed; most preservice teachers should score in the [higher] levels, with few preservice teachers scoring in the [lower levels]"' (p. 482). And so, it is possible that no matter how many teachers we would have tested, this competency would still have been strongly skewed. Nevertheless, it is possible we ran into a ceiling effect, and so in future iterations it may be necessary to specify dispositions further with more items.

The next objective we set out to accomplish was to find out if the pre-class and post-class surveys were comparable in order to eventually study the growth and change of preservice teachers during the course of a semester-long blended teaching class. This could then pave the way to someday study inservice teachers before and after inservice training. In order to do this, we needed to prove measurement invariance. Despite showing configural invariance over time for each competency, we could not demonstrate metric and scalar invariance for all of the competencies. Only Online Interaction had metric invariance, and none had scalar invariance. This means that although the structure of the latent variables remains constant over time, their changes in factor loadings and intercepts make them incomparable from one time period to another.

It is possible that with a larger sample size, the competency domains would have measurement invariance. As depicted on Table 4, no competency was particularly far off, and so this could be a result of being unable to use all of the participants' pre-class and post-class 
surveys. As stated above, we were only able to match 156 pre-class and post-class surveys of 326 participants.

However, we also acknowledge the possibility that because there is not demonstrable measurement invariance that the competencies' pre-class and post-class survey scores may actually represent different constructs (Van De Schoot, Schmidt, De Beuckelaer, Lek, \& Zondervan-Zwijnenburg, 2015). Perhaps, not only did the preservice teachers' feelings of competency change as they went through the course, but also their understanding of what the items meant and represented. For example, this student commented regarding the Online Integration competency, "I really feel that my knowledge and general perceptions of what it means to integrate technology into the classroom has changed so much thanks to this class." She then goes on to say that her original definition of Online Integration had now been elevated to something entirely different and more involved. This sentiment could justify thinking of it as a different construct altogether. We would expect less of this effect for inservice teachers who have had more experience with blended teaching competencies, as they would start and end a training with more or less the same definitions in mind.

\section{Limitations and Recommendations}

Though the survey was demonstrably shown to have convergence in the competency areas, and thus validate the model, we do caution that this survey may not be valid for unintended audiences who we have not yet studied. This survey was administered to a few hundred preservice teachers in the western United States, many of whom share several key demographic similarities, and so the results may not be identical to inservice teachers or international teachers who may have very different understandings and biases toward the subject matter treated in the instrument. Additionally, it should be noted that these preservice teachers 
participated in this survey as part of their class, and knew that their instructors would see the results. Despite the survey results having no bearing on their grade, and being completely anonymous to everyone except their instructor, it is possible the preservice teachers wanted to impress their instructor thus skewing the results more than would be desirable.

We recommend that future researchers and teacher trainers take advantage of our model and survey, and explore it in inservice and international contexts (or at any other institutions where blended teacher training occurs). The K-12 Blended Teaching Readiness survey and resources can be accessed online (see http://bit.ly.K12-BTR and http://edtechbooks.org/k12blended). We hope to eventually incorporate a knowledge instrument or an observation instrument to be used in tandem with this competency instrument to gain a better understanding of the differences between teachers' perceived and actual competencies. We also hope to someday compare the results from this survey to a future self-efficacy instrument.

\section{Conclusion}

Blended teaching and learning are not going away. As more and more primary and secondary schools shift to being blended, demand for quality teachers who can thrive in this modality has soared. This demand for trained teachers has far outstripped the research and development of training materials.

The framework and survey we created are meant to not only help prepare teachers to blend, but also lead the way for future research in blended teacher preparation. The framework we made, compared to prior frameworks, is simple, pedagogically-oriented, blended-focused, closely tied to the most current research, and free. Fittingly, the instrument we made to go along with the framework is also more approachable and parsimonious than previous iterations, 
allowing it to have more broad appeal, usage, and adoption (Whetten, 1989). It is our hope that these results will pave the way forward for continued model and instrument development, and research for blended teachers and their trainers. 


\section{References}

Archambault, L., Debruler, K., \& Freidhoff, J. R. (2014). K-12 Online and blended teacher licensure: Striking a balance between policy and preparedness. Journal of Technology and Teacher Education, 22(1), 83-106.

Archambault, L., Kennedy, K., Shelton, C., Dalal, M., McAllister, L., \& Huyett, S. (2016). Incremental progress: Re-examining field experiences in K-12 online learning contexts in the United States. Journal of Online Learning Research, 2(3), 303-326.

Arney, L. (2015). Go blended! A handbookfor blending technology in schools. San Francisco, CA: Jossey-Bass.

Barbour, M. (2008). What are they doing and how are they doing it? Rural student experiences in virtual schooling. In C. Bonk, M. Lee, \& T. Reynolds (Eds.), Proceedings of e-learn 2008-world conference on e-learning in corporate, government, healthcare, and higher education (pp. 2496-2503). Las Vegas, NV: Association for the Advancement of Computing in Education (AACE).

Barbour, M. K., Brown, R., Hasler Waters, L., Hoey, R., Hunt, J., Kennedy, K., Ounsworth, C., Powell, A., \& Trimm, T. (2011). Online and blended learning: A survey of policy and practice from K-12 schools around the world. Vienna, VA: International Association for K-12 Online Learning.

Barbour, M. K., Siko, J., Gross, E., \& Waddell, K. (2013). Virtually unprepared: Examining the preparation of K-12 online teachers. In Teacher education programs and online learning tools: Innovations in teacher preparation (pp. 60-81). Hershey, PA: IGI Global.

Barbour, M. K., \& LaBonte, R. (2017). State of the nation study: K-12 e-learning in Canada. Cobble Hill, BC: Canadian E-Learning Network. 
Bigatel, P. M., Ragan, L. C., Kennan, S., May, J., \& Redmond, B. F. (2012). The identification of competencies for online teaching success. Journal of Asynchronous Learning Networks, 16(1), 59-77.

Bjeki, D., Krneta, R., \& Milo, D. (2010). Teacher education from e-learner to e-teacher: Master curriculum. The Turkish Online Journal of Educational Technology, 9(1), 202-212.

Bollen, K. A. (1989). Structural equations with latent variables. Hoboken, NJ: John Wiley \& Sons.

Bonk, C. J., Kim, K. J., \& Zeng, T. (2005, June). Future directions of blended learning in higher education and workplace learning settings. In EdMedia+ innovate learning (pp. 36443649). Waynesville, NC: Association for the Advancement of Computing in Education (AACE).

Bonk, C. J. (2012). E-demand around the globe: Opener \#2: E-learning and blended learning (2012). doi:10.1002/9781118269381.ch3

Brodersen, R. M., \& Melluzzo, D. (2017). Summary of research on online and blended learning programs that offer differentiated learning options (REL 2017-228). Washington, DC: US Department of Education, Institute of Education Sciences, National Center for Education Evaluation and Regional Assistance, Regional Educational Laboratory Central. Retrieved from https://ies.ed.gov/ncee/edlabs/projects/project.asp?projectID=4499

Brown, T. A. (2006). Confirmatory factor analysis for applied research. New York, NY: Guilford Press.

Burkhardt, H., \& Schoenfeld, A. H. (2003). Improving educational research: Toward a more useful, more influential, and better-funded enterprise. Educational Researcher, 32(9), 314. 
Chen, F. F. (2007). Sensitivity of goodness of fit indexes to lack of measurement invariance. Structural Equation Modeling: A Multidisciplinary Journal, 14(3), 464-504. doi:10.1080/10705510701301834

Davis, N., Roblyer, M. D. (Peggy), Charania, A., Ferdig, R., Harms, C., Compton, L. K. L., \& Cho, M. O. (2007). Illustrating the "virtual" in virtual schooling: Challenges and strategies for creating real tools to prepare virtual teachers. The Internet and Higher Education, 10(1), 27-39. doi:10.1016/j.iheduc.2006.11.001

Dawley, L., Rice, K., \& Hinck, G. (2010). Going virtual! The status of professional development and unique needs of K-12 online teachers. Boise, ID: Boise State University.

DiPietro, M., Ferdig, R. E., Black, E. W., \& Preston, M. (2008). Best practices in teaching K-12 online: Lessons learned from Michigan Virtual School teachers. Journal of Interactive Online Learning, 7(1), 10-35.

Fan, W., Yan, Z. (2010). Factors affecting response rates of the web survey: A systematic review. Computers in Human Behavior, 26(2), 132-139.

Farrell, A. M., \& Rudd, J. M. (2009). Factor analysis and discriminant validity: A brief review of some practical issues. In D. Tojib (ed.), ANZMAC 2009 Conference Proceedings. Melbourne, Australia: ANZMAC.

Ferdig, R. E., Cavanaugh, C., Dipietro, M., Black, E. W., \& Dawson, K. (2009). Virtual schooling standards and best practices for teacher education. Journal of Technology and Teacher Education, 17(4), 479-503.

Flowers, C. (2006). Confirmatory factor analysis of scores on the clinical experience rubric: A measure of dispositions for preservice teachers. Educational and Psychological Measurement, 66(3), 478-488. 
Foulger, T. S., Graziano, K. J., Schmidt-Crawford, D., \& Slykhuis, D. A. (2017). Teacher educator technology competencies. Journal of Technology and Teacher Education, 25(4), 413-448.

Freidhoff, J. R., Borup, J., Stimson, R., \& DeBruler, K. (2015). Documenting and sharing the work of successful on-site mentors. Journal of Online Learning Research, 1(1), 107-128.

Graham, C. R. (2006). Blended learning systems: Definition, current trends, and future directions. In C. J. Bonk \& C. R. Graham (Eds.), Handbook of blended learning: Global perspectives, local designs (pp. 3-21). San Francisco, CA: Pfeiffer Publishing.

Graham, C. R. (2013). Emerging practice and research in blended learning. In M. G. Moore (Ed.), Handbook of distance education (3rd ed., pp. 333-350). New York, NY: Routledge.

Graham, C. R., Henrie, C. R., \& Gibbons, A. S. (2014). Developing models and theory for blended learning research. In A. G. Picciano, C. D. Dziuban, \& C. R. Graham (Eds.), Blended learning: Research perspectives (Vol. 2, pp. 13-33). New York, NY: Taylor \& Francis.

Graham, C. R., Borup, J., Pulham, E., \& Larsen, R. (2017). K-12 Blended Teaching Readiness: Phase 1-Instrument Development. Lansing, MI: Michigan Virtual University.

Graham, C. R., Borup, J., Pulham, E., \& Larsen, R. (2018). K-12 Blended teaching readiness: Phase 2 - instrument development. Lansing, MI: Michigan Virtual University.

Graham, C. R. (2019). Current research in blended learning. In M. G. Moore \& W. C. Diehl (Eds.), Handbook of distance education (4th ed., pp. 173-188). New York, NY: Routledge. 
Graham, C. R., Borup, J., Pulham, E., \& Larsen, R. (2019). K-12 blended teaching readiness: Model and instrument development. Journal of Research on Technology in Education, 51(3), 239-258. doi:10.1080/15391523.2019.1586601

Graziano, K. J., \& Bryans-Bongey, S. (2018). Surveying the national landscape of online teacher training in $\mathrm{K}-12$ teacher preparation programs. Journal of Digital Learning in Teacher Education, 34(4), 259-277.

Horn, M. B., \& Staker, H. (2014). Blended: Using disruptive innovation to improve schools. San Francisco, CA: Jossey-Bass.

International Society for Technology in Education. (2008). National educational technology standards for teachers. Retrieved from http://www.iste.org/docs/pdfs/nets-tstandards.pdf?sfvrsn=2

Johnson, J. (2014, January 20). Blended learning and technology integration [Video file]. Retrieved from https:/www.youtube.com/watch?v=KD8AUfGsCKg\&t=77s

Klein, J. D., Spector, J. M., Grabowski, B., \& de la Teja, I. (2004). Instructor competencies: Standards for face-to-face, online and blended settings (3rd ed.). Greenwich, CT: Information Age Publishing.

Molnar, A., Miron, G., Gulosino, C., Shank, C., Davidson, C., Barbour, . . \& \& Nitkin, D. (2017). Virtual schools report 2017. Boulder, CO: National Education Policy Center.

National Education Association. (2006). Guide to teaching online courses. Washington, DC: National Education Association.

Oliver, K. M., \& Stallings, D. (2014). Preparing teachers for emerging blended learning environments. Journal of Technology and Teacher Education, 22(1), 79-103. 
Oliver, W. L. (2014). Oliver's framework for blended instruction. Retrieved from http://blendedpractice.com

Porter, W. W., \& Graham, C. R. (2016). Institutional drivers and barriers to faculty adoption of blended learning in higher education. British Journal of Educational Technology, 47(4), $748-762$.

Powell, A., Rabbitt, B., \& Kennedy, K. (2014). iNACOL blended learning teacher competency framework. Retrieved from https://www.inacol.org/wpcontent/uploads/2014/10/iNACOL-Blended-Learning-Teacher-CompetencyFramework.pdf

Pulham, E., \& Graham, C. R. (2018). Comparing K-12 online and blended teaching competencies: A literature review. Distance Education, 39(3), 411-432.

Pulham, E. B., Graham, C. R., \& Short, C. R. (2018). Generic vs. modality-specific competencies for K-12 online and blended teaching. Journal of Online Learning Research, 4(1), 33-52.

Sims, R. C., \& Koszalka, T. A. (2008). Competencies for the new-age instructional designer. In Spector, J. M., Merrill, M. D., Elen, J., \& Bishop, M. J. (Eds.), Handbook of research on educational communications and technology (pp. 569-575). New York: NY: Springer.

Staker, H. (2011). The rise of K-12 blended learning: Profiles of emerging models. Retrieved from https:/www.christenseninstitute.org/wp-content/uploads/2013/04/The-rise-of-K-12blended-learning.emerging-models.pdf

Taylor, S., Clements, P., Heppen, J., Rickles, J., Sorensen, N., Walters, K., ... Micheiman, V. (2016). Getting back on track the role of in-person instructional support for students 
taking online credit recovery: Research brief 2. Washington, DC: American Institutes for Research.

The Learning Accelerator. (n.d.). Practices at work. Retrieved from http://practices.learningaccelera tor.org/

Tucker, C. R. (2012). Blended learning in grades 4-12: Leveraging the power of technology to create student-centered classrooms. Thousand Oaks, CA: Corwin Press.

Utah Department of Administrative Services. (2016) Utah Administrative Code. Retrieved from: http://www.rules.utah.gov/publicat/code/r277/r277-504.htm

Van De Schoot, R., Schmidt, P., De Beuckelaer, A., Lek, K., \& Zondervan-Zwijnenburg, M. (2015). Editorial: Measurement Invariance. Frontiers in Psychology, 6(1), 1064. https://doi.org/10.3389/fpsyg.2015.01064

Watson, J., Gemin, B., Pape, L., Vashaw, L., Hiett, B., Hiett, B., ... Comfort, J. (2015). Keeping pace with K-12 digital learning: An annual review of policy and practice. Evergreen Education Group. Retrieved from https://files.eric.ed.gov/fulltext/ED570125.pdf

Watson, J., Murin, A., Vashaw, L., Gemin, B., \& Rapp, C. (2011). Keeping pace with K-12 online learning: An annual review of policy and practice. Evergreen Education Group. Retrieved from http://kpk12.com/cms/wp-content/uploads/KeepingPace2011.pdf

Wang, J., \& Wang, X. (2012). Structural equation modeling: Applications using Mplus. Hoboken, NJ: John Wiley \& Sons.

Whetten, D. A. (1989). What constitutes a theoretical contribution? The Academy of Management Review, 14(4), 490-495. 


\section{APPENDIX A}

\section{Constructs and Items for Instrument}

\section{Table A1}

Confirmatory Factor Analysis Results (STDYX Standardization) for Blended Teaching Readiness Model Pre-Class Survey with Each Item's Description ( $=258$ Teachers).

\begin{tabular}{|c|c|c|c|c|}
\hline Item & $\Lambda$ & SE & Std. $\lambda \mathrm{a}$ & Comm b \\
\hline \multicolumn{5}{|l|}{ 1. Dispositions $(x=.300)$} \\
\hline $\begin{array}{l}\text { 1.1 I believe most students have better } \\
\text { learning outcomes when technology enables } \\
\text { them to adjust the pace of their own learning. }\end{array}$ & 1.000 & NA & .584 & 0.341 \\
\hline $\begin{array}{l}1.2 \text { I believe that online technology is critical } \\
\text { to implementing mastery-based learning in the } \\
\text { classrooms. }\end{array}$ & $1.451^{* *}$ & .181 & .647 & 0.419 \\
\hline $\begin{array}{l}1.3 \text { I believe online technologies enable } \\
\text { activities that would be difficult or impossible } \\
\text { to do otherwise. }\end{array}$ & $.782 * *$ & .118 & .487 & 0.237 \\
\hline $\begin{array}{l}1.4 \mathrm{I} \text { believe it is important for teachers to } \\
\text { explore new teaching strategies that blend in- } \\
\text { person and online learning. }\end{array}$ & $1.435^{* *}$ & .177 & .689 & 0.475 \\
\hline $\begin{array}{l}1.5 \text { I believe that students should use data to } \\
\text { guide their own learning progress. }\end{array}$ & $1.046^{* *}$ & .136 & .559 & 0.313 \\
\hline $\begin{array}{l}\text { 1.6 I believe that teachers who regularly use } \\
\text { data to inform their teaching will be able to } \\
\text { help their students more than those who don't. }\end{array}$ & $.837 * *$ & .128 & .493 & 0.243 \\
\hline $\begin{array}{l}1.7 \text { I believe that students need to gain } \\
\text { experience with online collaboration on } \\
\text { projects. }\end{array}$ & $1.071 * *$ & .175 & .557 & 0.31 \\
\hline $\begin{array}{l}1.8 \mathrm{I} \text { believe that student learning is enriched } \\
\text { when teachers and students interact in online } \\
\text { discussions. }\end{array}$ & $1.602 * *$ & .233 & .652 & 0.425 \\
\hline \multicolumn{5}{|l|}{ 2. Online Integration \& Management $(x=.753)$} \\
\hline \multicolumn{5}{|l|}{2.1 Integration } \\
\hline $\begin{array}{l}\text { 2.1.1 Evaluate the strengths and limitations of } \\
\text { specific online activities for your students. }\end{array}$ & 1.000 & NA & .777 & 0.604 \\
\hline
\end{tabular}


2.1.2 Strategically combine online and in-

when, where and how they

2.1.3 Determine when it is best to use

$1.183 * * \quad .067$

.857 computer-administered assessments.

2.1.4 Determine when it is most effective to

$1.059 * *$

.067

.789

0.622 interact with students online versus in person.

2.1.5 Discern when the use of online

$.989 * *$

.065

0.573 technologies improves learning outcomes and when it doesn't.

\section{$\underline{2.2 \text { Management }}$}

2.2.6 Develop procedures for the online created products (e.g. projects, reports, assignments, etc.)

2.2.7 Help students to manage their class learning activities.

2.2.9 Establish procedures for how students technology.

2.2.10 Establish guidelines that help students

2.2.11 Establish clear procedures to help students manage the use of individual and/or classroom devices (laptops, tablets, headphones, etc.)

\section{Data Practices $(x=1.090)$}

3.1 Identify patterns in small group and data. 
3.4 Use technology tools to monitor student

$1.178 * *$

.063

.833

0.694

participation levels (e.g. time on task,

attendance, logins, frequency of activity, etc.)

3.5 Use frequent online formative assessments

$1.085^{* *}$

.060

.861

0.741

to monitor student progress towards learning

outcomes.

3.6 Use online and offline assessment data to

$1.091 * *$

.057

.827

0.683

evaluate the effectiveness of accommodations for students with disabilities.

3.7 Use data collected online to determine

$1.124 * *$

.055

.859

0.738

which small groups or individual students

need additional instructional support.

3.8 Use technology to collect non-academic

$1.050 * *$

.070

.759

0.576

data that can inform personalization of instruction (e.g. interests, learning preference, background experiences, etc.)

\section{Personalization $(x=1.003)$}

4.1 Organize a set of online and offline

1.000

NA

.780

0.608 resources that support students in personalizing their projects.

4.2 Combine individual or small group

software to address specific student needs.

4.3 Use online tools to implement a mastery-

$1.104 * *$

.063

.846

0.716

based approach to learning.

4.4 Use educational software to customize

$1.151 * *$

.067

.869

0.755 student pathways through the curriculum.

4.5 Use technology that enables the pace of

$1.185 * *$

.070

.871

0.758 learning to be customized for each student.

4.6 Use technology to help students track

$1.167 * *$

.062

.863

0.744 progress on their personal learning goals.

4.7 Use technology to provide students with

4.8 Use technology to provide students with online options for how they demonstrate mastery of learning objectives.

5. Online Interaction $x=.803$

5.1 Establish clear expectations for respectful 
5.2 Establish clear boundaries when

$.969 * *$

.041

.751

0.564 communicating online that maintain professional student-teacher relationships.

5.3 Facilitate productive small group $1.211 * *$

.080

.836

0.699

collaborative project work that occurs both online and in-person.

5.4 Facilitate productive learner interaction in

$1.244^{* *}$

.95

.831

0.69 online discussion forums.

5.5 Facilitate productive video

$1.143 * *$

.104

.776

0.601

conferencing/webinar interactions with students and guest presenters.

5.6 Provide timely feedback to students using

$1.129 * *$

.079

.782

0.611

a variety of channels (text, audio, video, etc.)

5.7 Strengthen students' sense of belonging to

$1.165 * *$

.091

.807

0.651 the classroom community using online communication.

5.8 Create opportunities for students to help each other inside and outside of class using online technology. 


\section{Table A2}

Confirmatory Factor Analysis Results (STDYX Standardization) for Blended Teaching Readiness Model Pre-Class Survey with Each Item's Description ( $N=188$ Teachers).

\begin{tabular}{lllll}
\hline Item & $\boldsymbol{\Lambda}$ & $\mathrm{SE}$ & Std. $\lambda \mathrm{a}$ & Comm b
\end{tabular}

2. Online Integration \& Management $(\mathrm{x}=.308)$

\section{$\underline{2.1 \text { Integration }}$}

2.1.1 Evaluate the strengths and limitations of $\quad 1.000$ specific online activities for your students.

2.1.2 Strategically combine online and inperson activities that enable student ownership of their learning (e.g. flexibility in when, where and how they learn.

2.1.3 Determine when it is best to use computer-administered assessments.

2.1.4 Determine when it is most effective to interact with students online versus in person.

2.1.5 Discern when the use of online technologies improves learning outcomes and when it doesn't.

\subsection{Management}

2.2.6 Develop procedures for the online submission and management of studentcreated products (e.g. projects, reports, assignments, etc.)

2.2.7 Help students to manage their class related online accounts and passwords.

2.2.8 Provide clear procedures for transitioning between online and in-person learning activities.

2.2.9 Establish procedures for how students should seek help when learning with online technology.

2.2.10 Establish guidelines that help students use online time wisely.

2.2.11 Establish clear procedures to help students manage the use of individual and/or classroom devices (laptops, tablets, headphones, etc.)

$\begin{array}{llll}1.076 * * & 0.135 & 0.699 & 0.488\end{array}$

$\begin{array}{llll}1.174 * * & 0.143 & 0.704 & 0.496\end{array}$

$\begin{array}{llll}1.045^{* *} & 0.15 & 0.676 & 0.457\end{array}$

$\begin{array}{llll}1.111^{* *} & 0.121 & 0.737 & 0.543\end{array}$

$\begin{array}{llll}1.000 * * & \text { NA } & 0.729 & 0.532\end{array}$

$\begin{array}{llll}1.046^{* *} & 0.162 & 0.586 & 0.344\end{array}$

$\begin{array}{llll}1.009 * * & 0.107 & 0.701 & 0.492\end{array}$

$\begin{array}{llll}1.189 * * & 0.121 & 0.773 & 0.597\end{array}$

$\begin{array}{llll}1.231^{* *} & 0.135 & 0.752 & 0.565\end{array}$

$\begin{array}{llll}1.039^{* *} & 0.123 & 0.735 & 0.54\end{array}$ 


\section{Data Practices $(x=.501)$}

3.1 Identify patterns in small group and

1.000

NA

0.743

0.553 whole-class learning based on online and offline assessment data.

3.2 Help students track their own learning

$1.031 * *$

0.091

0.685

0.47 progress using online and offline assessment data.

3.3 Interpret mastery-based progress

$1.028 * *$

0.087

0.718

0.515 dashboards to inform interventions for individuals and small groups.

3.4 Use technology tools to monitor student

$1.015^{* *}$

0.099

0.722

0.522 participation levels (e.g. time on task, attendance, logins, frequency of activity, etc.)

3.5 Use frequent online formative assessments $1.022 * *$ outcomes.

3.6 Use online and offline assessment data to for students with disabilities.

3.7 Use data collected online to determine need additional instructional support.

3.8 Use technology to collect non-academic data that can inform personalization of instruction (e.g. interests, learning preference, background experiences, etc.)

\section{Personalization $(\mathrm{x}=.483)$}

4.1 Organize a set of online and offline resources that support students in personalizing their projects.

4.2 Combine individual or small group instruction with the use of educational software to address specific student needs.

4.3 Use online tools to implement a mastery- 
4.7 Use technology to provide students with flexibility in where they learn.

4.8 Use technology to provide students with online options for how they demonstrate mastery of learning objectives.

\section{$\underline{\text { 5. Online Interaction }(x=.136)}$}

5.1 Establish clear expectations for respectful online communication between students.

5.2 Establish clear boundaries when communicating online that maintain professional student-teacher relationships.

5.3 Facilitate productive small group collaborative project work that occurs both online and in-person.

5.4 Facilitate productive learner interaction in online discussion forums.

5.5 Facilitate productive video conferencing/webinar interactions with students and guest presenters.

5.6 Provide timely feedback to students using a variety of channels (text, audio, video, etc.)

5.7 Strengthen students' sense of belonging to the classroom community using online communication.

5.8 Create opportunities for students to help each other inside and outside of class using online technology.
$1.031 * * \quad 0.104 \quad 0.795$

0.631

$0.963 * * \quad 0.105$

0.747

0.558

1.000

NA

0.524

0.274

$1.066^{* *}$

0.144

0.521

0.271

$2.119 * *$

0.408

0.812

0.659

$2.066^{* *}$

0.352

0.778

0.605

$2.279 * *$

0.444

0.683

0.467

$1.516^{* *}$

0.246

0.657

0.431

$2.236^{* *}$

0.432

0.745

0.554

$2.256^{* *}$

0.395

0.839

0.703 


\section{APPENDIX B}

\section{Institutional Review Board Approval Letter}

\section{BYU}

InSTITUTIONAL REVIEW BoARD

For Human Subjects

\section{Memorandum}

To: Professor Charles Graham

Department: IP\&T

College: EDUC

From: Sandee Aina, MPA, IRB Administrator

Bob Ridge, PhD, IRB Chair

Date: May 31, 2019

IRB\#: E19155

Title: "IPT373 Archival Data-Blended Teaching Readiness"

Brigham Young University's IRB has approved the research study referenced in the subject heading as exempt level, categories 1 and 4 . This category does not require an annual continuing review. Each year near the anniversary of the approval date, you will receive an email reminding you of your obligations as a researcher and to check on the status of the study. You will receive this email each year until you close the study.

The study is approved as of May 31, 2019. Please reference your assigned IRB identification number in any correspondence with the IRB.

Continued approval is conditional upon your compliance with the following requirements:

1. Any modifications to the approved protocol must be submitted, reviewed, and approved by the IRB before modifications are incorporated in the study.

2. In addition, serious adverse events must be reported to the IRB immediately, with a written report by the PI within 24 hours of the PI's becoming aware of the event. Serious adverse events are (1) death of a research participant; or (2) serious injury to a research participant.

3. All other non-serious unanticipated problems should be reported to the IRB within 2 weeks of the first awareness of the problem by the PI. Prompt reporting is important, as unanticipated problems often require some modification of study procedures, protocols, and/or informed consent processes. Such modifications require the review and approval of the IRB. Please refer to the IRB website for more information.

IRB Secretary

A 285 ASB

Brigham Young University

(801)422-3606 


\section{APPENDIX C}

\section{Annotated Bibliography}

\section{Introduction}

The purpose of this annotated bibliography is to familiarize myself with the prior research done in the field of blended learning, particularly in teacher preparation, as well as learn about creating theoretical contributions to the field. Consequently, the scope of this bibliography includes seminal works defining blended learning, seminal works detailing how to create theoretical contributions, oft-cited guides detailing the methodology for this kind of research, and current articles describing the state of teacher preparation and competency creation for blended environments and the challenges they face.

This bibliography is divided into four sections: (1) blended learning definition and trends, (2) blended teacher preparation, (3) blended teacher competencies, and (4) developing and validating a blended learning theory.

To find literature for this bibliography, I had a four part system. First, I searched for sources that were foundational to the works that my research is built on. The works my research is based on are Pulham and Graham, (2018); Pulham, Graham, and Short (2018); and Graham, Borup, Pulham, and Larsen (2019). This search revealed many of the articles I will rely on for justifying theory, validating competencies, and using SEM. To know which of these to include in my annotated bibliography, I looked them up on Google Scholar to determine their impact and citations. If they had a high impact and over a hundred citations I knew they would be worth including in this bibliography. Second, I searched for seminal articles on blended learning and blended teaching competencies using the Oxford Annotated Bibliography for blended learning developed in Graham (2016), as well as two literature reviews by Graham (2013) and Pulham 
and Graham (2018). I incorporated any article that was labeled seminal and foundational in those sources. Third, I searched for "online K-12 teacher preparation," "blended teacher preparation," and "digital teacher preparation" on the ERIC database and Google Scholar in order to identify relevant articles on efforts to train K-12 teachers in blended environments. Fourth, I determined which of these to include by how well they connect with my own topic, thus favoring articles that were K-12 over higher ed, and blended over online. How recent these articles were published was also a determining factor in their inclusion.

\section{Blended Learning Definitions and Trends}

This section includes seminal articles that are pivotal in defining the field of blended learning (Graham, 2006; Singh, 2003), that attempt to harmonize multiple definitions of the field (Graham, 2013; Shea, 2007), and that justify the field (Garrison \& Kanuka, 2004). This section

also includes recent articles that discuss current growth (Watson et al., 2015; Graham, 2019), and trends in blended learning (Ferdig \& Kennedy, 2014). The purpose of these articles in my research is to establish a holistic understanding of what blended learning is, where it came from as a field, and give an idea as to its growth in the K-12 sector. Thus, laying the foundation for why validated competency standards are needed.

Graham, C. R. (2006). Blended learning systems: Definition, current trends, and future directions. In C. J. Bonk \& C. R. Graham (Eds.), The handbook of blended learning: Global perspectives, local designs (pp. 3-21). San Francisco, CA: Pfeiffer.

This article was written near the beginning of blended learning research, and has become a seminal work. It laid the groundwork for defining and categorizing elements of the field as well 
as established the future directions for research in the field. One of its main contributions is defining blended learning as the combination of online and face-to-face instruction, and justifying that definition.

Graham, C. R. (2013). Emerging practice and research in blended learning. In M. G. Moore (Ed.), Handbook of distance education (3rd ed., pp. 333-350). New York, NY: Routledge.

This literature review comprehensively examines past and present research of blended learning. Particularly relevant to the research at hand is this review's foray into finding prominent K-12 education models. It discusses Watson's 7 defining dimensions for establishing how blended a K-12 classroom was, the Innosite Institute's matrix for determining school blending, and the four models defined by Staker and Horn (2012).

Singh, H. (2003). Building effective blended learning programs. Educational Technology, 43(6), $51-54$

This seminal article defines common elements and tools of blended classrooms. Among those elements are traditional instructor-led training, synchronous online conferencing, asynchronous self-paced study, and structure training from an experienced mentor. Among those tools are synchronous collaboration software, self-paced web-based courses, electronic performance support systems (EPSS), and knowledge management systems. The article was an early 
justification for blended learning, showing that blending was effective because it leveraged the strengths of two modalities making it cheaper and more efficient.

Shea, P. (2007). Towards a conceptual framework for learning in blended environments. In A. G. Picciano \& C. D. Dziuban (Eds.), Blended learning: Research perspectives (pp. 19-35). Needham, MA: The Sloan Consortium.

This seminal book discusses lenses through which blended learning can be viewed. One lens is seeing blended learning as a way to expand access so that students with varying time constraints can still participate. Another, is to view it as a way to more effectively align instruction on the conditions laid out in the How People Learn Framework (HPL). Essentially, this is accomplished by having learner-centered, knowledge-centered, assessment-centered, and community-centered instruction. The affordances of blended learning place it in a unique position to accurately center instruction according to these conditions.

Garrison, D. R., \& Kanuka, H. (2004). Blended learning: Uncovering its transformative potential in higher education. The Internet and Higher Education, 7(1), 95-105. doi:10.1016/j.iheduc.2004.02.001

This paper discusses how the revolutionary approaches of blended learning can transform the higher education landscape, and resolve many of its challenges. It is important for this research paper because it is a seminal article discussing the vision and aspirations of blended learning. It also justifies blended learning as an effective and meaningful method. 
Watson, J., Gemin, B., Pape, L., Vashaw, L., Hiett, B., Hiett, B., ... Comfort, J. (2015). Keeping pace with K-12 digital learning: An annual review of policy and practice. Evergreen Education Group. Retrieved from https://files.eric.ed.gov/fulltext/ED570125.pdf

The Evergreen Education group keeps tabs on the growth and prevalence of K-12 blended and online learning in the United States. Specifically relevant to this research is its report that from 2011-2015 the number of students enrolled in K-12 blended education programs have increased by $80 \%$ and that blended learning is becoming more prevalent across the United States.

Graham, C. R. (2019). Current research in blended learning. In M. G. Moore \& W. C. Diehl (Eds.), Handbook of distance education (4th ed., pp. 173-188). New York, NY: Routledge.

This chapter provides evidence that the estimates of the Keeping Pace with K-12 Online Learning reports may be underestimating the amount of growth in blended learning as their numbers do not distinguish between blended and fully online. Indeed, it appears that most of the digital learning growth happening in the country is blended. And most of that growth is occurring in high school, where as of $2009,40 \%$ of districts had a blended program, with another $20 \%$ in the process. Resulting in $80 \%$ of blended learners being in high school.

Ferdig, R. E., \& Kennedy, K. (Eds.). (2014). Handbook of research on k-12 online and blended learning. Halifax, NS: ETC Press. 
This is a book focused entirely on the history and research of K-12 blended learning specifically. The book is useful for highlighting many of the advantages blended learning classes offer. Advantages such as increased access and lower costs are especially apparent. In regards to it actually improving student outcomes to traditional classrooms, the book takes a nuanced approach: the blended programs can be better but it all depends on how prepared and accountable they were in their implementation.

\section{Blended Teacher Preparation}

This section focuses on why it is difficult to prepare teachers to teach in blended settings (Brodersen \& Melluzzo, 2017; Davis et al., 2007; Horn \& Staker, 2014). It dives into the lack of preparation happening, and posits why there is such a lack (Archambault et al., 2016; Barbour, Siko, Gross, \& Waddell, 2013; Graziano \& Bryans-Bongey, 2018). One of the reasons for the lack of preparation boils down to government policy (Archambault, Debruler, \& Freidhoff, 2014). Other articles look at what preparation current blended teachers would have liked to receive, and what elements contribute to successful preparation (Dawley, Rice, \& Hinck, 2010; Ferdig, Cavanaugh, Dipietro, Black, \& Dawson, 2009). These articles prove that there is a need for greater emphasis on teacher preparation, and illustrate how helpful a set of standard validated competencies could be in effecting campus and government policy change.

Davis, N., Roblyer, M. D. (Peggy), Charania, A., Ferdig, R., Harms, C., Compton, L. K. L., \& Cho, M. O. (2007). Illustrating the "virtual" in virtual schooling: Challenges and strategies for creating real tools to prepare virtual teachers. Internet and Higher Education, 10(1), 27-39. 
Teaching parts of a course online has unique challenges and requires distinct skills. Virtual teachers need to specialize in student retention skills, reducing student feelings of isolation, troubleshooting technical problems, collaborating with curriculum designers and facilitators, and helping students self-regulate. However, the demand for teachers prepared with the skills to teach online has vastly outpaced the supply. 86,000 teacher candidates graduate each year without any online teaching skills.

Ferdig, R. E., Cavanaugh, C., Dipietro, M., Black, E. W., \& Dawson, K. (2009). Virtual schooling standards and best practices for teacher education. Journal of Technology and Teacher Education, 17(4), 479-503.

This article rightly distinguishes that research that applies to face-to-face and adult education pedagogies does not always translate to K-12 online and blended pedagogies. The article then synthesizes best practice guidelines various programs have to train their online K-12 teachers to reach the intersection of pedagogy, technology, and content (TPCK). It notes a major theme of these guidelines are that online teachers end up taking on several roles beyond teaching: they become a counselor, mentor, facilitator, instructional designer, site coordinator, and administrator.

Barbour, M. K., Siko, J., Gross, E., \& Waddell, K. (2013). Virtually unprepared: Examining the preparation of K-12 online teachers. In Teacher education programs and online learning tools: Innovations in teacher preparation (pp. 60-81). Hershey, PA: IGI Global. 
This article discusses the extent to which teacher education programs fail to prepare teachers for online environments. Less than $40 \%$ of online teachers reported receiving any professional development before they began teaching online. It discusses how some institutions in North America have remedied this dearth of training by providing teacher candidates with field experiences, integrating technology courses throughout a teacher candidate's education, or offering specialized certificates of online teaching skills.

Dawley, L., Rice, K., \& Hinck, G. (2010). Going virtual! The status of professional development and unique needs of K-12 online teachers. Boise, ID: Boise State University. Retrieved from http://edtech.boisestate.edu/goingvirtual/ goingvirtual3.pdf

A report focused on what makes an online teacher's experience different from a face-to-face teacher. The authors find that online teachers are often teachers with lots of face-to-face experience, with $73 \%$ reporting more than 6 years of experience. However, these experienced teachers report that they need more professional development especially in regards to learning communication technologies $(74 \%)$, time management strategies $(62 \%)$, risks of academic dishonesty to learners (60\%), and student internet safety.

Horn, M. B., \& Staker, H. (2014). Blended: Using disruptive innovation to improve schools. San Francisco, CA: Jossey-Bass. 
This book discusses blended learning as a disruptive innovation in K-12 settings. Consequently, it highlights in what ways a blended classroom is different from a more traditional face-to-face classroom. For example, blended classrooms are far more focused on "Student-Centered Learning," a type of learning which consists of personalization, tailoring content and assessments to student needs and abilities, and competency-based learning, encouraging students to work until they achieve mastery rather than quit working when the due date is reached.

Brodersen, R. M., \& Melluzzo, D. (2017). Summary of research on online and blended learning programs that offer differentiated learning options (REL 2017-228). Washington, DC: US Department of Education, Institute of Education Sciences, National Center for Education Evaluation and Regional Assistance, Regional Educational Laboratory Central. Retrieved from https://ies.ed.gov/ncee/edlabs/projects/project.asp?projectID=4499

This report synthesizes the findings of 17 research studies done in $11 \mathrm{~K}-12$ blended learning classrooms with significant differentiation options for students. The report goes into great depth describing how these blended classrooms were very different from online classrooms. Among those differences were blended teachers chose to communicate differently with their students, choosing face-to-face communication over phone or email. Additionally, the blended classrooms were proven to use what happens online to inform classroom instruction, a feat requiring distinct data analysis skills. 
Graziano, K. J., \& Bryans-Bongey, S. (2018). Surveying the national landscape of online teacher training in K-12 teacher preparation programs. Journal of Digital Learning in Teacher Education, 34(4), 259-277.

This article examines how education programs prepare teacher candidates to teach in online and blended contexts. After surveying 215 deans and administrators, they found that because of an overabundance of state requirements on traditional teaching, they do not have the room or resources to support online or blended initiatives and students do not have the time.

Additionally, many of the deans reported a lack of experienced faculty, student interest, and funding as other barriers to supporting online and blended training.

Archambault, L., Kennedy, K., Shelton, C., Dalal, M., McAllister, L., \& Huyett, S. (2016). Incremental Progress: Re-examining field experiences in K-12 online learning contexts in the United States. Journal of Online Learning Research, 2(3), 303-326.

Previously, in 2010, the authors surveyed teacher education administrators to find out how many online field experiences were being provided and why/why not. This current study iterated on that. The current study found the creation of eight more programs across six more states, putting the numbers up to 15 and nine respectively. The growth, while encouraging, is still modest. And there are still significant barriers to overcome. For example, only $40 \%$ of administrators believe their program should offer field experiences, and many are confused by what being an online teacher actually entails. 
Archambault, L., Debruler, K., \& Freidhoff, J. R. (2014). K-12 online and blended teacher licensure: Striking a balance between policy and preparedness. Journal of Technology and Teacher Education, 22(1), 83-106.

This article uses the TPCK model to define a quality online and blended teacher, and then compares these traits to existing requirements for teacher licensure across the US. One of the key findings is that only Georgia, Idaho, Michigan, Louisiana, South Carolina, South Dakota, Utah, and Vermont have "adopted online teacher standards and have created a state-level teaching license dealing with online teaching." It notes the benefits of having a national set of standards, however, laments the fact that they are not recognized by districts and teachers as having much value.

\section{Blended Teacher Competencies}

This section dives into what is the method behind creating blended teacher competencies (Bigatel, Ragan, Kennan, May, \& Redmond, 2012). Following that, it shows examples of how previous competencies were created (Powell, Rabbitt, \& Kennedy, 2014; Foulger, Graziano, Schmidt-Crawford, \& Slykhuis, 2017). Finally, this section contains a literature review weighing the strengths and weaknesses of the different competencies (Pulham \& Graham, 2018) and a critique of the existing competencies for being too generic (Pulham, Graham, \& Short, 2018). By showing methods and examples of creating competencies, and demonstrating their gaps, I am able to assert the importance of validated competencies. 
Bigatel, P. M., Ragan, L. C., Kennan, S., May, J., \& Redmond, B. F. (2012). The identification of competencies for online teaching success. Journal of Asynchronous Learning Networks, 16(1), 59-77.

This article uses a survey on 197 online teachers in order to identify what roles and responsibilities they feel they have that are unique to them teaching online. Through their exploratory factor analysis, seven competency themes emerged: (1) active learning (helping students stay engaged and interacting with each other), (2) leadership/administration (using technology in a way that enhances student experience), (3) active teaching responsiveness (providing detailed feedback), (4) multimedia technology (using a variety of effective media to support teaching), (5) classroom decorum (encouraging collaboration and resolving conflict), (6) technological competence, and (7) policy enforcement.

Powell, A., Rabbitt, B., \& Kennedy, K. (2014). iNACOL blended learning teacher competency framework. Retrieved from https://www.inacol.org/wpcontent/uploads/2014/10/iNACOL-Blended-Learning-Teacher-CompetencyFramework.pdf

In tandem with the Learning Accelerator, the International Association for K-12 Online Learning developed a flexible competency framework specifically for supporting K-12 blended teachers. The competencies begin with mindsets (being oriented towards change and improvement), qualities (choosing to be collaborative, transparent, and determined to succeed), and possessing two types of skills: adaptive (having communication and self-reflection skills), and technical. 
Additionally, it highlights that blended classes are competency-based, equitable, and personalized.

Foulger, T.S., Graziano, K.J., Schmidt-Crawford, D., \& Slykhuis, D.A. (2017). Teacher educator technology competencies. Journal of Technology and Teacher Education, 25(4), 413448.

These teacher educator technology competencies (TETCs) were developed to support all teacher educators in helping teacher candidates integrate technology into their classrooms. They focus on skills like helping teachers learn how to troubleshoot technology problems, be advocates for technology, use technology to differentiate student learning, and use relevant online tools. There is specific mention of teacher educators being able to model blended environments and provide opportunities for teacher candidates to practice teaching in these environments.

Pulham, E., \& Graham, C. R. (2018). Comparing K-12 online and blended teaching competencies: A literature review. Distance Education, 39(3), 411-432.

This comprehensive literature review details the various competency frameworks that have been developed for blended teachers. It finds that among the competencies developed, the following skills consistently emerge as global themes: flexibility and personalization, mastery-based learning, data usage and interpretation, learning management system usage, online discussion facilitation, and software management. 
Pulham, E. B., Graham, C. R., \& Short, C. R. (2018). Generic vs. modality-specific competencies for K-12 online and blended teaching. Journal of Online Learning Research, 4(1), 33-52.

This review illustrates that almost all of the competency frameworks developed for blended teachers actually have very few skills that are unique to the blended modality. $71 \%$ of iNACOL's competencies are generic, $82 \%$ of the competencies in Virtual Schooling Standards and Best Practices for Teacher Education are generic, and $71 \%$ of competencies in Oliver's Framework for Blended Instruction are generic. Rigorous studies are needed to determine specifically blended competencies, and those should be what are emphasized in teacher education programs aiming to help teachers blend.

\section{Developing and Validating Blended Theory}

Because the validated competencies will be contributing to blended theory, this section details how to contribute to theory in general (Whetten, 1989) and specifically how to contribute to theory in the field of blended learning (Graham, Henrie, \& Gibbons, 2014). Additionally, this section points to the gap in blended theory that this contribution will fill (Burkhardt \& Schoenfeld, 2003). This section then shifts focus to the methods that will allow this research to contribute to that gap in theory. It discusses the background behind creating the survey instrument and the studies that informed its creation (Dabbagh \& English, 2015; Darabi, Sikorski, \& Harvey, 2006; Graham, Borup, Pulham, \& Larsen, 2019; Klein, Spector, Grabowski, $\&$ de la Teja, 2004). Finally, it incorporates the specific statistical tools and methods necessary in order to validate that survey instrument (Schumacker \& Lomax, 1996; Wang \& Wang, 2012). 
Whetten, D. A. (1989). What constitutes a theoretical contribution? The Academy of Management Review, 14(4), 490-495.

This is the seminal work defining what elements comprise a theoretical contribution. Though theories often incorporate many variables and values, the primary contribution of a theory is it provides a model for understanding relationships. Thus, when a new theory is proposed it needs to show how new factors change the understanding of the underlying relationships. Additionally, to be useful, new theories have to walk the line between comprehensiveness and parsimony. This article is important for my research, as I am trying to validate theoretical contributions to the field of blended learning.

Burkhardt, H., \& Schoenfeld, A. H. (2003). Improving educational research: Toward a more useful, more influential, and better-funded enterprise. Educational Researcher, 32(9), 314.

This seminal article provides the impetus for validating the survey instrument in my research. This is because this article demonstrates a dangerous tendency of partitioning in educational research between the theory-developing researchers and the practitioners. Often, the work of the two parties never meets. The authors call for "engineering" research to be done, work that is both practical and theoretical that will bridge the gap. By validating the survey instrument, my research is bridging the gap between the competency theory developed by Pulham and Graham (2018) and transforming it into a measurement tool for teachers and teacher educators. 
Graham, C. R., Borup, J., Pulham, E. B., \& Larsen, R. (2019). K-12 blended teaching readiness: Model and instrument development. Journal of Research on Technology in Education.

Blended learning implementation has far outpaced blended learning research. An example of that is the fact that there exist few frameworks for specifically blended teaching competencies, and among these none are validated. After two years of research, this study produces the first validated self-assessment instrument of its kind for K-12 blended teaching competencies. It was created for teachers to "self-assess their readiness, school district leaders to support their implementation and evaluation of BL initiatives, and researchers to explore the efficacy of professional development efforts."

Graham, C. R., Henrie, C. R., \& Gibbons, A. S. (2014). Developing models and theory for blended learning research. In A. G. Picciano, C. D. Dziuban, \& C. R. Graham (Eds.), Blended learning: Research perspectives (Vol. 2, pp. 13-33). New York, NY: Taylor \& Francis.

This chapter highlights the issue that very little blended learning theory is actually being developed. The current research being done primarily consists of identifying surface level characteristics rather than diving deep into pedagogy. This means that up to this point, many of the attempts to create competencies have been the results of exploratory or case studies. 
Klein, J. D., Spector, J. M., Grabowski, B., \& de la Teja, I. (2004). Instructor competencies: Standards for face-to-face, online and blended settings (3rd ed.). Greenwich, CT: Information Age Publishing.

The International Board of Standards for Training, Performance and Instruction releases competencies for online and face-to-face instructors in this report. These competencies, despite not being specific to K-12 blended teaching, are a valuable guide to creating and validating competency frameworks for teachers. Among the competencies listed are foundational skills like communication, planning skills, instructional strategies, assessment skills, and management skills.

Darabi, A. A., Sikorski, E. G., \& Harvey, R. B. (2006). Validated competencies for distance teaching. Distance Education, 27(1), 105-122.

This study uses the IBSTPI methodology to develop their own distance education instructor competencies. After a thorough literature review, they formulated a list of 20 separate competencies. From there, they were delivered to subject matter experts who divided the 20 competencies into 54 tasks. The tasks then went to 148 instructors who rated the tasks in terms of importance. The top five tasks were (1) manage logistics of the course, (2) utilize communication skills, (3) provide learners with course-level guidelines, (4) evaluate effectiveness, and (5) assess student learning according to course standards. 
Dabbagh, N., \& English, M. (2015). Using student self-ratings to assess the alignment of instructional design competencies and courses in a graduate program. TechTrends, 59(4), $22-31$.

In this study, the authors use survey instruments for measuring instructional designers' perceptions of their competencies according to the competency standards of several different organizations. It is similar to my own study in that they use self-reports to measure competencies. The key takeaway is that they were able to use this instrument to evaluate the effectiveness of their instructional design courses as well as to identify gaps in the students' knowledge.

Schumacker, R. E., \& Lomax, R. G. (1996). A beginner's guide to structural equation modeling. Mahwah, NJ: Lawrence Erlbaum Associates.

Structural equation modeling (SEM) is a statistical method used to determine to what extent a theoretical model is supported by sample data. Because the survey in my study is based on a complex competency theoretical framework, and has many variables at play, and because I need to validate a survey instrument and account for measurement error, structural equation modeling is the answer for me. This guidebook leads researchers on a step-by-step process through SEM to help them determine the model, software, and variables they should use.

Wang, J., \& Wang, X. (2012). Structural equation modeling: Applications using Mplus. Hoboken, NJ: John Wiley \& Sons. 
This reference book dives deeper into structural equation modeling, discussing more advanced models and using Mplus programming syntax. Particularly relevant for this research, is chapter 2 that details the methods and logic behind confirmatory factor analysis (CFA). CFA is the method I will be using to determine the goodness of fit for the survey, and it was how the theoretical structure of the competencies were validated. 